\title{
ECONOMIC ASPECTS OF US INVOLVEMENT IN CENTRAL ASIA
}

\author{
Botir B. Ochilov,
} Fellow at the University of World Economy and Diplomacy, Tashkent, Uzbekistan

b.ochilov@list.ru ORCID ID orcid.org/0000-0001-5897-1051

\section{Crossref}

http://dx.doi.org/10.26739/2433-202x

Issue DOI http://dx.doi.org/10.26739/2433-202x-2017-6-6

Article DOI http:/ /dx.doi.org/10.26739/2433-202x-2017-6-6-5

Since the mid-1990s till 2008 the economic direction remained one of the key elements of the US policy towards Central Asian countries. Fundamental characteristics of the region are geographical remoteness and transport and communication isolation, degree of development of market infrastructure in the countries and specifics of geopolitical strategy of the USA for Russia, Iran and China.

Key words: Central Asia, the USA, Russia, energy resources, economic assistance 
Geographical remoteness of Central Asia and its transport isolation created difficulty of involvement of the American companies to implementation of projects on economic development of the region. At the same time, Washington understands of the importance of transport and communication infrastructure for transforming geopolitical situation in Central Asia put to the center of American strategy in the region development of the transport communications alternative to the routes lying through the territory of Russia. At this point development of alternative ways of delivery of hydrocarbon resources of Central Asia to the international market gained special importance.

In the beginning, Clinton administration assumed that Moscow should represent itself as the «locomotive» or «policeman» in Central Asia and Transcaucasia that should undertake all the expenditures and expenses of the control over its traditional domain of influence. But then the situation changed, after 1996 the so-called «Talbott's doctrine», which stated that nobody should receive obvious prevalence in this region; in fact, it meant the necessity of keeping of Moscow from active penetration into the region under cover of care of «neighboring countries».

As the most noticeable practical measure of implementation of the Talbott's doctrine, Clinton administration attempted to organize construction of the pipeline of Baku-Tbilisi-Ceyhan along «the Caucasian corridor» which had to prevent pipeline «monopoly» of Moscow which, according to the American strategists, sought to launch all pipelines across its territory.

Tactics chosen by the USA in many respects suited the interests of the countries of the region. During 1990s' and the beginning of 2000s' this Social science and humanities

Ochilov B. 
approach became guarantee of progressive expansion and development of interaction between the republics of the Central Asia and the USA. Such steps of the USA can be evaluated as positive for formation and strengthening of independence and sovereignty of the Central Asian states, especially at the first stages of development.

At the same time, it should be noted that over time the position of the USA in economic sphere became one-sided, Washington not always took into consideration the real dynamics of development of the countries of Central Asia. In particular, change of the structures of their economies and also evolution of the interests of the states of the region in the economic sphere. It became clear that focus on development of hydrocarbon potential of the region in fact put the countries of Central Asia in the same position in which they were during the Soviet period - in position of suppliers of resources and sales markets of final goods. To some extent, the USA realized this fact. In particular, according to Blank, access to energy resources of Central Asia, though is important, but «is not and should not be the main driver of the US policy. Rather it has to be a tool. Opening access to the global markets for the countries of Central Asia, and at the same time, providing unimpeded access of the energy companies will allow the Central Asian governments to diversify customers and to get access to the markets where they will be able to sell their goods at reasonable prices. In this sense the driving force of the US policy is the strategy of support of «anti-monopolism» whereas policies of Moscow and Beijing are monopolistic by nature» 1 .

Therefore, 15 years of independence of Central Asia, as well as after the events of September 11, 2001 and following considerable expansion of

\footnotetext{
${ }^{1}$ Blank S. The Strategic Importance of Central Asia: An American View // Parameters, Spring 2008, p. 74. Social science and humanities

Ochilov B.
} 
cooperation between the countries of the region and the USA within the framework of anti-terrorist campaign, Washington still continued to adhere to the line of conduct formulated as far back as in the mid-1990s: until Central Asian energy resources are monopolized by Russia by means of control of routes of their transportation, the governments of these Post-Soviet states would not be able to carry out effective economic or foreign policy.

One more aspect, though it is not discussed often, but deserves attention, is connected with the fact that transformation of energy resources to the key (or even the only) driver of economic growth of the countries of the region has objectively brought to an essential gap in the level of social and economic development between the countries of Central Asia. In countries allocated with rich hydrocarbon resources ${ }^{2}$, high oil and natural gas revenues were reflected in rapid and significant growth in GDP. The growth in incomes was promoted by not only the increase in production, but also much more by the rise in the world prices. In particular, from 2002 to 2008 oil prices grew five times, from 21-22 US dollars for barrel to more than 100.

\footnotetext{
${ }^{2}$ In Central Asia, it is Kazakhstan and Turkmenistan, in the Caucasus - Azerbaijan that the US and the West considered as an important central element of the regional strategy in competition for the Caspian oil and the development of alternative transport infrastructure.

Social science and humanities

Ochilov B.
} 


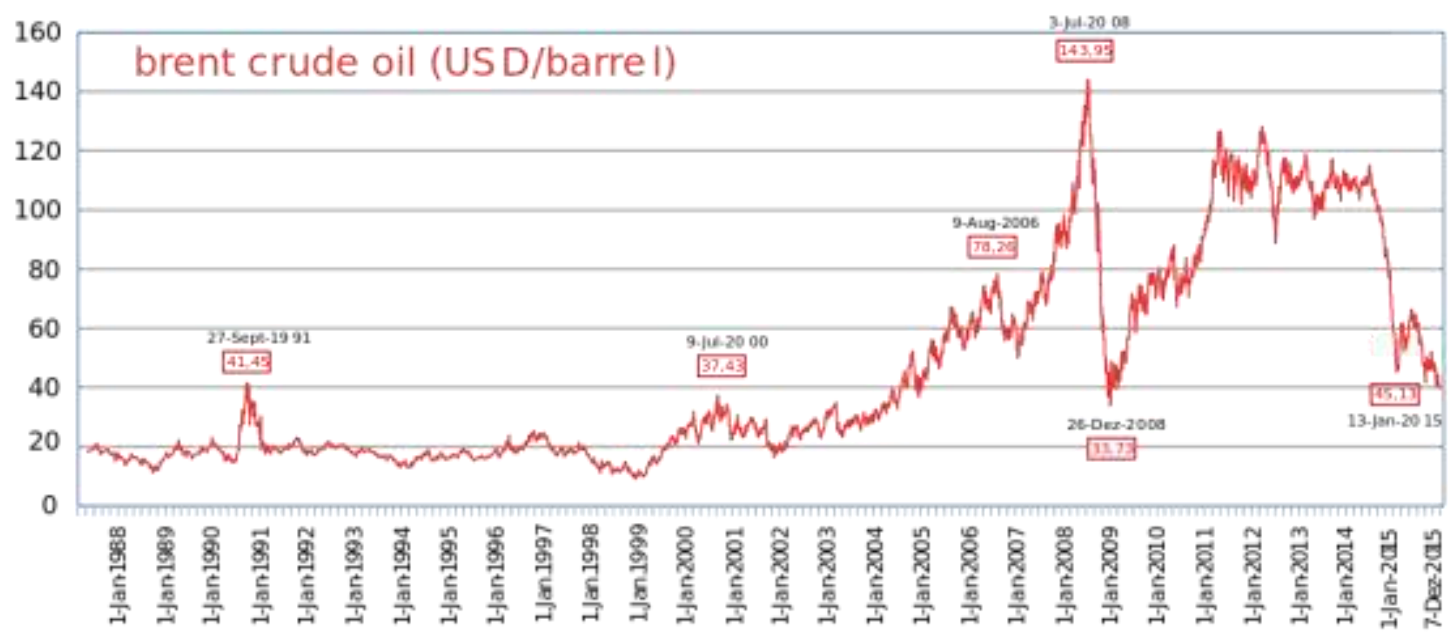

Figure 1. Brent Crude Oil Spot Price Range in World Market for 1988-2015, USD/Barrel

Source: Wikipedia, oil prices ${ }^{3}$

In oil-producing countries, growth in incomes of the population was not connected with an adequate increase in labor productivity in economy, in particular in its non-oil sectors.

From 2000 to 2008, levels in per capita GDP in the current prices between Kazakhstan and Tajikistan were $\$ 5813$ and $\$ 711$ in 2008. In 2000, this indicator was equal to $\$ 1229$ and $\$ 139$, the gap has increased from 10 to 100 times ${ }^{4}$.

The countries, poor in hydrocarbon resources - Kyrgyzstan and Tajikistan -appeared in serious dependence on the incomes of labor migrants, which arrived mainly from Russia and Kazakhstan. Thus, before the world financial and economic crisis of 2008-2009 the remittances of labor migrants accounted for about $23 \%$ of GDP in Kyrgyzstan, in Tajikistan - about $52 \%$ of GDP5 5 . In Russia and Kazakhstan increase in demand for labor from abroad

\footnotetext{
${ }^{3}$ https://ru.wikipedia.org/wiki/oil_prices

${ }^{4}$ The GDP per capita is estimated in the current prices in US dollars (the World Bank data).

5 . http://siteresources.worldbank.org/INTECA/Resources/CanagarajahRemittancesR.pdf 
has been caused not only (and not so much) by demographic specifics, but by a significant gap in salary levels which has developed as a result of economic transformations in Russia and Kazakhstan.

During this period, Russia and Kazakhstan became attractive markets for export of certain goods (mainly agricultural products) from the countries of Central Asia, in particular, from Kyrgyzstan, Uzbekistan and Tajikistan. Such situation promoted rather rapid economic growth and increase in welfare of the population in all countries of Central Asia. At the same time, the model of growth based on high income from export of hydrocarbons in the certain countries and redistribution of a part of this income to other countries through labor migration turned out to be quite unstable. It became obvious after 2008, when the volume of money transfers decreased by $31 \%$ in Tajikistan and by $20 \%$ in Kyrgyzstan in 2009 with reference to the level of $2008^{6}$.

Degree of development of market infrastructure in the countries of the Central Asian region reduced its appeal for foreign, including American, investments. In particular, absence of the developed financial market and relatively high risks of business made the region unattractive for the American business, especially in comparison with the fast-growing markets of the countries of Southeast Asia. In this regard the US administration defined as one of the strategic tasks the deepening of market transformations in the countries of the region, especially stimulated accession to the WTO, actively supported those western companies, first of all energy companies, which would plan projects in Central Asia.

6 Ibid. 
Assistance to liberal economic reforms was one of the segments of the strategy of «involvement», proclaimed by Clinton administration as the response to new challenges and opportunities that were opened by the collapse of the USSR and emergence of the new independent states. This strategy assumed involving one or another country in international trade, in network of the international organizations and contracts, development of cultural ties and tourism. As a result of the gained advantages and the promised benefits such country starts to do more and more concessions, to refuse odious plans and gradually will be transformed into «the normal country» (from the point of view of the USA).

The humanitarian aid, financial and technical assistance allocated by the USA to the countries of the region within various programs acted as one of the tools by means of which this strategy was implemented. The amount of such assistance to the countries of Central Asia for the solution of security issues, which was allocated within the framework of «The Freedom Support Act» and the programs within budgets of the ministries and departments from 1992 for 2008, was about $\$ 1.5$ billion, and a considerable part of these means were directed to Kazakhstan. 


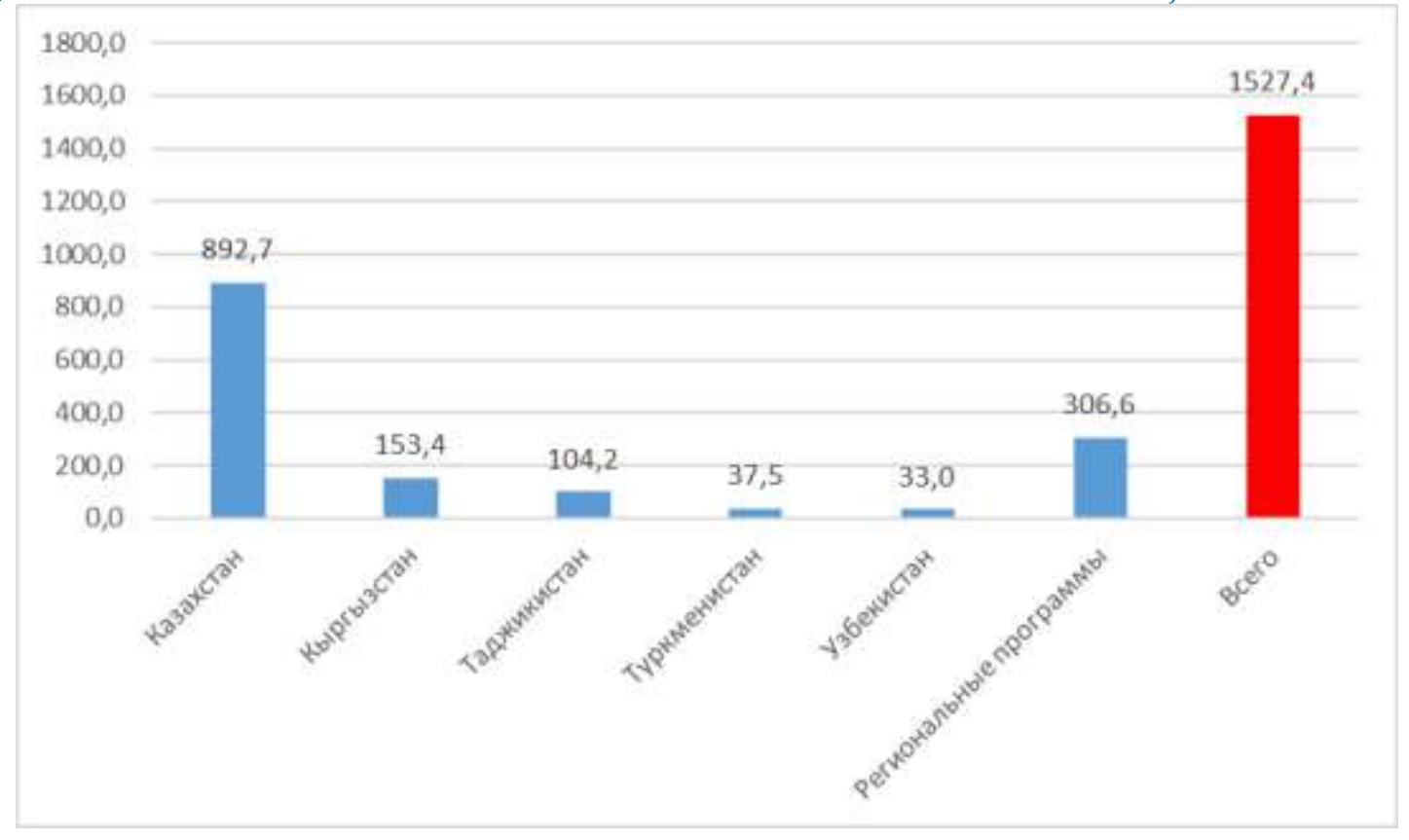

Figure 2. Amount of US assistance to the countries of Central Asia in the sphere of security in 1992-2008, $\mathrm{mln}$ USD

Source: Jim Nichol. Central Asia's Security: Issues and Implications for U.S. Interests. Congressional Research Service. March 11, 2010.

More and more American investments were widely attracted to the region, volumes of bilateral trade continuously increased. As early as in 1993 the Chevron Corporation and the leadership of Kazakhstan signed the agreement on formation of joint venture «Tengizshevroil» for mining Tengiz , one of the most perspective fields of hydrocarbons in Kazakhstan. By 2012, American investments into the economy of Kazakhstan accounted \$ 17.9 billion, and cumulative investments from the developed countries have exceeded $\$ 110$ billion7. For comparison: by 2012, the amount of American investments into Uzbekistan accounted for, by different estimates, a little more than $\$ 2$ billion ${ }^{8}$.

\footnotetext{
7 Нацбанк раскрыл главных инвесторов Казахстана. Рынки. Tengrinews.kz. 12 января, 2013 г. https://tengrinews.kz/markets/natsbank-raskryil-glavnyih-investorov-kazahstana-226516/

8 Узбекско-американский $\quad$ бизнес-форум прошел $\quad$ в $\quad$ Ташкенте. Газета.уз, 17 августа 2012 г. https://www.gazeta.uz/ru/2012/08/17/forum/.

Social science and humanities

Ochilov B.
} 
Mutual trade is one of the indicators that traditionally characterizes the relations between the countries. Undoubtedly, geographical remoteness and difficulties with transport communications left the mark on volumes and dynamics of trade relations between the USA and the countries of Central Asia. According to the ADB experts, total commodity turnover between the US and the countries of Central Asia in 1992-2012 accounted for about \$33.3 billion, at the same time about $65 \%$ were the share of Kazakhstan (Table 1).

Table 1. Trade Volumes between the countries of Central Asia and the USA in 1992-2012, mln USD

\begin{tabular}{|c|c|c|c|c|}
\hline Country & Years & Export & Import & $\begin{array}{c}\text { Commodity } \\
\text { turnover }\end{array}$ \\
\hline \multirow[t]{3}{*}{ Kazakhstan } & 1992-1999 & 0,53 & 1,15 & 1,68 \\
\hline & 2000-2012 & 6,76 & 13,22 & 19,98 \\
\hline & Total & 7,29 & 14,37 & 21,66 \\
\hline \multirow[t]{3}{*}{ Kyrgyzstan } & $1992-1999$ & 0,09 & 0,29 & 0,38 \\
\hline & 2000-2012 & 0,10 & 1,02 & 1,12 \\
\hline & Total & 0,19 & 1,31 & 1,50 \\
\hline \multirow[t]{3}{*}{ Tadjikistan } & 1992-1999 & 0,08 & 0,16 & 0,24 \\
\hline & $2000-2012$ & 0,04 & 0,63 & 0,67 \\
\hline & Total & 0,12 & 0,79 & 0,91 \\
\hline \multirow[t]{3}{*}{ Turkmenistan } & 1992-1999 & 0,09 & 0,91 & 1,00 \\
\hline & 2000-2012 & 1,04 & 1,99 & 3,03 \\
\hline & Total & 1,13 & 2,90 & 4,03 \\
\hline \multirow[t]{3}{*}{ Uzbekistan } & 1992-1999 & 0,27 & 1,50 & 1,77 \\
\hline & $2000-2012$ & 1,18 & 2,24 & 3,42 \\
\hline & Total & 1,45 & 3,74 & 5,19 \\
\hline \multirow{3}{*}{$\begin{array}{l}\text { All countries of } \\
\text { Central Asia }\end{array}$} & 1992-1999 & 1,06 & 4,01 & 5,07 \\
\hline & $2000-2012$ & 9,12 & 19,10 & 28,22 \\
\hline & Total & 10,18 & 23,11 & 33,29 \\
\hline
\end{tabular}

Source: Asian Development Bank Institute ${ }^{9}$

${ }^{9}$ Connecting Central Asia with Economic Centers. Asian Development Bank Institute, 2014. 
The USA paid special attention to Kazakhstan due to the existence of arsenals of weapons of mass destruction of the former USSR, situated in the territory of this republic. However, this attention can also be explained by at least two more factors. The first: large reserves of oil that could be directed to the lobbied by Washington oil pipelines from Central Asia to the markets of the developed countries. The second: having extended border with Russia Kazakhstan is «the classical buffer state» and therefore its government constantly cares for "preserving good relations with all neighbors, but without allowing that the presence of more powerful states in its territory assumes too big scale» ${ }^{10}$.

Kazakhstan with its huge reserves of resources and extensive territory, but with a difficult demographic situation can be considered as the country which is the most subject to external and internal challenges and threats. Its political space for maneuvers is also significantly limited by the neighborhood with Russia and China ${ }^{11}$. In this regard, active political and economic presence of the West in Kazakhstan, ensuring as much as possible independent policy of the Kazakhstani leaders from Moscow were one of the key tasks of the American strategy for weakening of monopolistic influence of Russia in the region.

It appears that Kazakhstan has geopolitical opportunities and limitations. Seeking to use as much as possible advantages, Nazarbayev in one of his program statements known as «Kazakhstan - 2030» had designated as a priority the use of the geographical location of the country «at

\footnotetext{
10 Брауэр Б. Борьба за влияние в Центральноазиатском регионе: влияние Китая остается ограниченным // Internationale Politik, 2002, № 2. - C. 29.

${ }^{11}$ See further: Fairbanks Ch., Starr F., Nelson C., Weisbrode K. Strategic Assessment of Central Eurasia. - Washington, D.C. 2001. P.33.

Social science and humanities

Ochilov B.
} 
the intersection of roads in the Eurasian continent». The system of political and economic priorities which was called «multi-vector» policy had been established.. It implied three main directions - the West (the USA and Europe), the East (China, Japan) and the North (Russia). Directions the «West» and the «East» pursued two aims: to create oil pipelines for export of the oil to the markets of Europe and the Asian-Pacific region and to realize the transport potential of Kazakhstan. The «northern» direction was under the influence of the Russian Federation, the Kazakh side sought to make it as constructive as possible.

It should be noted that the oil and gas sector, though it was priority for the USA in economic terms, was not the only capital investment sphere in the region. For example, as early as in 1992 the Uzbekistan-American joint venture «Zarafshan-Newmont» was created. One more transnational corporation -Nukem Inc. took strong positions in the market of uranium in Uzbekistan since the beginning of the 1990s. The contract between Nukem Inc. and the Uzbek side has been concluded also in 1992 and gave to the American side exclusive rights on acquisition of the Uzbekistan uranium till 2011'12. This contract, besides the economic, had also political reasons, connected with security issues and geopolitics. Thus, the involvement of the USA into the export of the uranium from Uzbekistan was the part in agreements on non-proliferation regime of the WMD and export control, at the same time it is necessary to consider that Russia after the collapse of the USSR was left without large-scale deposits of uranium, and Russian nuclear industries - without raw materials. Possessing considerable reserves of

12 World Nuclear Association. http://www.world-nuclear.org/information-library/country-profiles/countries-tz/uzbekistan.aspx; U.S. company Nukem Inc. to keep on purchasing uranium in Uzbekistan // The Times Of Central Asia, August 20, 2012. http://www.timesca.com/index.php/news/9537-us-company-nukem-inc-to-keep-on-purchasinguranium-in-uzbekistan 
uranium, Uzbekistan was attractive for Russian companies, but Russia faced serious competition for the right to develop the uranium along with the Japanese and South Korean companies in Uzbekistan ${ }^{13}$.

The study and analysis of the bilateral economic relations between the USA and the countries of Central Asia allows to make the following conclusion. Appealing and pushing in every possible way the countries of Central Asia to liberalization of economic policy, especially their trade regimes, nevertheless the USA did not intend to propose concrete measures and projects which would help the countries of the region to resolve complex issues of economic development, including the implementation of structural reforms in economy for the increase in welfare of the population, the sustainable development of each country.

Characteristics of geopolitical strategy of the US for Russia, Iran and China. Understanding the importance of Central Asia for world politics, in particular, for implementation of their strategy in Eurasia, the US, nevertheless, showed lack of serious interest in relation to the region. On this occasion American analysts expressed their opinions and evaluations, representatives of the American political establishment made statements, but for the leadership of the US, Central Asia always mattered only in the context of the American strategy in Eurasia. Therefore, the American policy for the countries of the region subordinated to the interests and tasks, often tactical, concerning relations of the USA with major regional powers such as Russia, Iran, China, etc. In this regard, for most American companies Central Asia

\footnotetext{
${ }^{13}$ Ваганов А. Урановая трещина. России скоро будет не обойтись без Узбекистана // Независимая газета от 12.07.2006 г.

Social science and humanities

Ochilov B.
} 
remained to be an area where the US administration may not provide sufficient support.

One of striking examples in this context are the relations of the USA with Iran. The Iranian territory could become the most acceptable route of transportation of energy resources from Central Asia to world markets and also for gaining access to the region on automobile and trunk railways. American and some European energy companies tried to lobby the removal of sanctions from Tehran, as from the point of view of economic feasibility the route through the Iranian territory is more acceptable than the project of the pipeline of Baku-Tbilisi-Ceyhan even on condition of connection of deliveries from Kazakhstan and Turkmenistan by the trans Caspian pipelines.

Some western companies showed interest in the oil and gas sector of Russia that made the opposition between Washington and Moscow around the Caspian energy resources undesirable. In practice geopolitical aspirations of Washington often won over economic rationality. So, in November, 1999 the president Bill Clinton signed the project of the pipeline of Baku-TbilisiCeyhan. The project was estimated for $\$ 2.7$ billion, and construction would come to the end in 2005 and subsequently the West would receive $40 \%$ of energy resources from this region. In his plans Bill Clinton put a special emphasis on the active participation of the corporate sector, envisaged western private capital to realize this plan, paying for construction of the pipeline. However, corporations did not agree, as they were indifferent to the geostrategic plans of the US administration and preferred cheaper ways of transportation through Russia or Iran. It slowed down the development of the project, the pool did not develop and in 2000 in Azerbaijan several «dry» Social science and humanities

Ochilov B. 
wells were drilled, many in the West began to consider the assessment of the region «as alternative to the Persian Gulf» only as «the propaganda run».

From the beginning of the 1990s the views of Washington on the prospect of the expansion of China's presence in Central Asia started to undergo essential adjustments. So, if in the first half of the 1990s the factor of the PRC was not even taken into consideration during the formulation and realization of the American strategy in Central Asia, then in the second half of the 1990s the growing Chinese involvement in the region started to be considered in Washington as a challenge namely as one more major power which is potentially aimed at monopolization of Central Asia. However, since the beginning of the 2000s Chinese pipeline projects, in particular the gas pipeline Turkmenistan-Uzbekistan-China, became a real alternative to the Russian routes. 